\title{
The Role of Student Subjectivity in Successful Professional Self-determination
}

\author{
Svetlana Khrebina ${ }^{1}$, Lyubov Voronkina ${ }^{1}$, Rimma Zvereva ${ }^{1}$, Margarita \\ Shapovalova ${ }^{1 *}$
}

\author{
${ }^{1}$ Pyatigorsk State University, Pyatigorsk, Russia \\ *Email:rey71@mail.ru
}

\begin{abstract}
The article reveals the psychological aspects of the development of students' subjectivity as a condition for successful professional self-determination in studying at a university.

The content of the concept of the subjectivity of a student's personality as a quality that allows to effectively and consciously form a professional Self is substantiated. The criteria for determining the level of the subjectivity of a student are determined. These included: motivational, intellectual, emotional and volitional qualities of the student's personality, which determine his ability to change himself and the surrounding reality.

The diagnostic tools are described, and the results of an experimental study aimed at studying the peculiarities of the development of the subjectivity of the student's personality and its influence on professional self-determination are presented.

The psychological conditions of the systemic formation of the components of the student's subjectivity in the university's educational environment are revealed. The structure, tasks and topics of classes of the program of psychological support of students, contributing to the development of their subjectivity as a condition for successful professional selfdetermination of students in the learning process, are determined.
\end{abstract}

Keywords: Subjectivity, Professional Self, Psychological support, Development of subjectivity, Successful professional self-determination, Psychological readiness, Educational activity.

\section{INTRODUCTION}

The significance of the development of subjectivity of students is confirmed by the content of the National Doctrine of Education in the Russian Federation until 2025, which asserts the need to mobilise personal potential, preserve integrity, reproduce the quality of subjectivity in each person, i.e. the desire of a person to be reflected in life, culture, significant others as "Myself". According to the provisions of the same "National Doctrine of the Development of education in Russia", the problem of the development of students as future subjects of professional activity is not solved in the learning process, as a result of which certain difficulties arise in the process of professional selfdetermination. Because professional self-determination is a multidimensional and multi-stage process of determining a person's professional purpose, it should not proceed chaotically but should be purposefully built.

The subjectivity of the student's personality is the quality that allows you to actively, independently and consciously carry out forming a professional Self. The subjectivity of a student's personality is the motivational, intellectual, emotional and volitional qualities of a person that determine a person's ability to make changes in the surrounding reality and himself. We have identified 4 criteria for determining the level of the subjectivity of a student: the implementation of his own choice; the presence of specific life goals; activity in planning his own life; activity in building his own life [1]. Despite recognising the importance of subjectivity and the practicality of its development in the educational space, most of the studied activity and personal characteristics 
of the subjectivity of students' personality are not in the focus of attention of the system of psychological support of education in higher educational institutions. All this necessitated the development and testing of a program for psychological support of the development of the subjectivity of the subject's personality, which will contribute to self-development and self-improvement of significant personality characteristics necessary for both successful studies and successful professional selfdetermination. Professional self-determination is the implementation of the process of self-knowledge and correlation of results with the demands of the external environment: it is the establishment of a balance between one's preferences and capabilities and the requirements of professional activity that are the guarantee of successful self-determination.

We assume that psychological support for the development of students' personality subjectivity contributes to forming a professional Self, which determines the success of professional selfdetermination. This is the process of realising who I am and who I can become. The link between these processes is the so-called stage of self-knowledge and internal audit of the individual, the results of which should be correlated with the analysis of the external environment, its requests and challenges. Given the fact that professional self-determination is a multidimensional and multi-stage process of determining a person's professional purpose, it should not proceed chaotically. Therefore, a stable and, to a certain extent, universal algorithm for building a professional Self should be developed based on the analysis of existing theoretical developments.

\section{RESEARCH METHODOLOGY}

The theoretical and methodological foundations of the study are theoretical provisions on the mechanisms and patterns of human development as a subject of activity, communication, cognition, relationships and the relationship of personal and subjective characteristics: K. A. Abulkhanova, V.V. Bogdanovich, A.V. Brushlinsky, V.V. Signs, E.A. Sergiyenko A. A. Bodalev, A.K. Osnitsky A.A. Derkach, D.N. Zavalishina, V.I. Slobodchikov, D.I. Feldstein, T.V. Prokofiev [2] et al.; research on the uniqueness of subjectivity as a personal education: S.V. Hrebina [3], N.M. Borytko, E.N. Volkova, E.I. Kazakova, F.G. Mukhametzyanova, A.K. Osnitsky, V.A. Petrovsky, V.I. Slobodchikov, A.A. Pligin [4]; problems of professional development of a person as a subject of various types of activity: E. N. Volkova, L.A. Nedoseka [5], E.A. Klimov, A. K. Markova, L.M. Mitina, S.V. Hrebina [3], L.B. Voronkina [1], Yu. P. Povarenkov, et al.)

\section{RESEARCH RESULTS}

The problem of subjectivity has become the subject of scientific analysis in the research of many Russian psychologists: S.L. Rubinstein, A.V. Brushlinsky, K.A. Abulkhanov-Slavskoy, B.G. Ananyev, A.L. Zhuravleva, O.A. Konopkin, A.K. Osnitsky, V.A. Petrovsky, V.I. Slobodchikova, V.A.Tatenko, A.I. Shakimanskaya et al. The concept of the subject itself has the status of a central concept of psychology, but at the same time, it is insufficiently developed and does not have a single generally accepted definition [1]. In general, the term "subject" refers to an individual as the owner of activity, the carrier of certain mental properties and qualities, including subjectivity, among other things. By subjectivity, most researchers understand the central formation of human reality, which arises at a certain level of personality development and implies the ability to change the surrounding reality and oneself.

Scientists (L.S. Vygotsky, M.M. Rubinstein, L.G. Desfronteynes, I.S. Kon, M. Kle, G. Kraig, E. Erikson, et al.) identify the following characteristics that are most significant for developing subjectivity: self-awareness, self-reflection, self-control, self-regulation, independence [3].

Of all the ages of the development of personality subjectivity, scientists attach special importance to the student's age since this period is the most sensitive for the manifestation of a student's personal subjectivity. Psychological support for the development of the student's subjectivity in the university's educational process can ensure the realisation of intrapersonal potential and contribute to the self-improvement and selfdevelopment of the individual. The development of subjectivity as an integration structure implies the dynamics of its constituent qualities.

The modern higher education system does not provide a solution to the problems of education and development of students as future subjects of professional activity. Still, at the same time, several studies confirm the importance of developing professional "I" and professional self-determination at the student age for the successful adaptation of specialists in the profession [5]. Due to the multidimensionality and multi-step nature of the process of professional selfdetermination, it is necessary to support it by specialists and assist students in building a professional "Self" [6].

Subjectivity as a quality meets the requirements of becoming a future specialist, as it represents the unity of such processes as the transformation of oneself and the transformation of reality. It is through subjectivity that the foundations for the formation of the professional Self are laid and developed; the process of professional selfdetermination occurs when the choice of the goals of the future specialist's life activity occurs consciously and 
corresponds not only to their own needs and capabilities but also to the needs of society [4]

Thus, psychological support for developing the subjectivity of the subject's personality contributes to self-development and self-realisation in educational and social activities and successful professional selfdetermination.

The experimental study was organised and conducted under the set goal: to study the peculiarities of the development of the subjectivity of the student's personality and its influence on professional selfdetermination. 127 students participated in this study: 70 students were respondents of the experimental group, 57 students represented the control group. For a comprehensive psychological survey, several diagnostic techniques were selected: the method of M. Kun and T. McPartland's "Who am I?"; test for determining the level of self-actualisation of the personality of E. Shostrom in the modification of L.Ya. Gozman (SAT test); Rotter's "Locus of control" method; test "Life orientations" (LO); diagnostics of the properties of self-regulation" (A.K. Osnitsky); methodology for studying the statuses of professional identity; questionnaire "DDQ Methodology" ("Differential diagnostic questionnaire" by E.A.Klimov); D.Holland's test for determining the type of personality; methodology "Motives for choosing a profession" (R.V. Ovcharova).

The study results allowed us to conclude that some students' studied characteristics of subjectivity are insufficiently developed. Professional self-determination of students cannot be considered successful since their chosen profession in some cases did not coincide with the type of personality and preferred type of professions. Some students were diagnosed with an uncertain or imposed professional identity and a crisis of choice.

The study of the material on the problem of developing the subjectivity of the student's personality as a condition for successful professional self-determination led us to conclude that the system formation of the entire set of components of subjectivity is necessary. Based on the analysis of methodological literature, we have developed a program for developing the subjectivity of the student's personality as a condition for successful professional self-determination. After the testing of the program, we organised a control stage of the study and conducted a re-diagnosis of the characteristics of subjectivity and the features of professional selfdetermination of students. The results of the control stage of the study allow us to draw conclusions about the undoubted effectiveness of the program developed by us for the development of the subjectivity of the personality of students: in the experimental group, the level of formation of the characteristics of subjectivity and the indicators of the success of professional selfdetermination significantly increased compared with the indicators of the ascertaining diagnosis. The indicators of the control group did not undergo significant changes.

\section{THE PROGRAM FOR THE DEVELOPMENT OF THE SUBJECTIVITY OF THE STUDENT'S PERSONALITY AS A CONDITION FOR SUCCESSFUL PROFESSIONAL SELF-DETERMINATION}

The study of the material on the problem of developing the subjectivity of the student's personality as a condition for successful professional self-determination led us to conclude that the system formation of the entire set of components of subjectivity is necessary. The program aims to develop the subjectivity of the student's personality as a condition for successful professional self-determination.

To this goal, the following objectives of the program are put forward:

1. Training in self-knowledge skills; improving the adequacy of self-esteem; creating conditions for personal growth.

\section{Assistance in professional self-determination.}

Justification of the program's significance: the period of study in higher education institutions falls during the most intensive psychological and social formation of the personality, its maturation, the student's awareness of his role and place in society [7]. Ideas about the near and distant future play a vital role in human behaviour and life. Building a life perspective implies putting forward milestone goals, developing ways to achieve them, and reflecting on the meaning of achieving these goals. An individual's life prospects, clear awareness, range, reliability, etc., are determined by professional, family, and age self-determination in life, which depends on the individual's socio-psychological and social maturity and activity [8].

Professional self-determination of students is a complex, lengthy and multifaceted process. Professional self-determination is considered as a process covering the entire period of a person's professional activity: from the emergence of professional intentions to retirement from work [9]. It permeates the entire life path of a person. The most crucial criterion for the awareness and productivity of a person's professional development is her ability to find personal meaning in professional work, independently design, create her professional life, responsibly make decisions about choosing a profession, speciality and place of work. Constant clarification of the place in the world of occupations, comprehension of one's socio-professional role, attitude to a professional career, the team and oneself become essential components of a person's life. Professional selfdetermination is carried out throughout professional life: a person constantly reflects, rethinks professional being 
and confirms Self in the profession [10]. Professional self-determination is an important factor of personal selfrealisation in a particular profession and culture in general.

The program is presented as training sessions to develop specific skills and abilities and create conditions for participants' self-disclosure, self-exploration, and self-understanding. This program is intended for students whose personal and professional development issues are the most relevant. blocks:

We have developed a program that consists of six

1. Introductory educational work;

2. Training "The way to myself or who am I?";

3. Training "Goal setting and building a life perspective";

\section{Training "Professional self-determination";}

5. Training "Obstacles and resources in professional self-development".

\section{Training "CV writing skills".}

Self-improvement and self-improvement involve only the analysis of mistakes and the struggle with their weaknesses. There is another equally, if not more, important aspect of working on yourself. It consists in discovering in oneself not only an opponent and a culprit but also an associate, friend and assistant - in this we see the importance of a subjective approach to the process of professional self-determination [11]. Some people believe that they do not possess any qualities that could serve as an internal fulcrum. Strange as it may seem, most people do not know how to think about themselves positively. It should be noted that "strengths" are not the same as "positive character traits" or "virtues". It also happens that some quality or skill turns out to be a very strong side of the personality, but the surrounding people do not approve of it, or it does not meet moral standards. Therefore, if we analyse "strengths" only as an opportunity for a person to find inner support, it is essential to consider what a person uses his strengths for. Harmonious development is possible only when a person can adequately assess all his qualities, abilities, and himself as a whole. The formation of adequate selfesteem is possible only by accurately determining one's strengths and weaknesses, knowledge about oneself as a person in general, i.e. self-knowledge [12]

The thematic content of the program:

1. Introduction to the training atmosphere.

2. Creating conditions for forming the desire for selfknowledge, immersion in your inner world and orientation in it.
3. Mastering knowledge about yourself as an integral subject, finding your "self-image".

4. Overcoming psychological barriers that prevent full self-expression, mastering self-regulation techniques.

5. Forming and developing the attitude to selfknowledge and self-development.

6. Developing personally important qualities: professional reflection, empathy, criticality and flexibility of attitudes.

7. Promoting awareness of one's life prospects, life goals, ways and means of achieving them.

\section{CONCLUSION}

Summarising the above, it should be noted that the modern higher education system does not provide a solution to the problems of education and development of students as future subjects of professional activity. Still, at the same time, several studies confirm the importance of developing professional "Self" and professional self-determination at the student age for the successful adaptation of specialists in the profession. Due to the multidimensionality and multi-step nature of the process of professional self-determination, it is necessary to support it by specialists and assist students in building a professional "Self".

Subjectivity as a quality meets the requirements of becoming a future specialist, as it represents the unity of such processes as the transformation of oneself and the transformation of reality. It is through subjectivity that the foundations of the formation of the professional Self are laid and developed; the process of professional selfdetermination occurs when the choice of the goals of the future specialist's life activity occurs consciously and corresponds not only to their own needs and capabilities but also to the needs of society.

For successful professional self-determination, a systematic formation of the entire components of subjectivity is necessary. We have identified the following criteria for determining the level of the subjectivity of a student: the implementation of his own choice; the presence of specific life goals; activity in building his own life. The program proposed by us, developed based on these criteria, contributes to developing the subjectivity of the student's personality as a condition for successful professional selfdetermination.

Moreover, this approach to the organisation of career guidance activities can be successfully implemented in various organisations and territories, making it flexible and universal in its way. Of course, any approaches require analysis and timely updating, which is carried out by us regularly and considering the dynamics of the 
labour market, which requires a modern person, on the one hand, to clearly define his professional Self, on the other hand, to build a flexible professional self that can adapt to a changing environment.

\section{REFERENCES}

[1] L.B. Voronkina, On the development of subjective aspects of thinking in students, personality as a subject of managerial activity [ $\mathrm{K}$ voprosu razvitiya sub"ektnyh aspektov myshleniya u uchashchihsya, Lichnost' kak sub"ekt upravlencheskoj deyatel'nosti] // Collection of scientific papers [Sbornik nauchnyh trudov], Pyatigorsk: PSU 9 (2017) 8-15.

[2] T.V. Prokofiev, The formation of a teenager's subjectivity in educational activities [Stanovlenie sub"ektnosti podrostka v uchebnoj deyatel'nosti], Retrieved from: http://www.childpsy.ru/upload/dissertations

[3] S.V. Khrebina, Broadcasting of personality subjectivity in the conditions of modern education, Psychological aspects [Translirovanie sub"ektnosti lichnosti v usloviyah sovremennogo obrazovaniya, Psihologicheskie aspekty] // In the collection: University Readings - 2020: Materials of scientific and methodological readings of PSU [V sbornike: Universitetskie chteniya - 2020: Materialy nauchno-metodicheskih chtenij PGU], 2020, pp. 127-132.

[4] A.A. Pligin, The development of subjectivity of schoolchildren: from methodology to educational concept and technology [Razvitie sub"ektnosti shkol'nikov: ot metodologii - $\mathrm{k}$ obrazovatel'noj koncepcii i tekhnologii], Retrieved from: http://www.piligin.ru/artides/razvitie_subektnosti2 $\underline{010 . h t m .}$

[5] L.A. Nedoseka, The development of student subjectivity as a factor in improving the quality of specialist training at the University [Razvitie sub"ektnosti studenta kak faktor povysheniya kachestva podgotovki specialista v Vuze], Retrieved from:

http://t21.rgups.ru/archive/doc.2008/5/12.doc.

[6] S.V. Khrebina, M.V. Khrebin, E.A. Terentieva, M.L. Shapovalova, R.N. Yundin, Psychological correlations of the development of student's readiness for self-realisation in the process of professional training, Advances in Intelligent Systems and Computing, 726 (2019) 1101-11081. DOI: https://doi.org/10.1007/978-3-319-90835$\underline{9} 124$
[7] M.L. Shapovalova, E.F. Serdyukova, Transformation of integral individuality of students with different ways out of difficult life situations [Transformaciya integral'noj individual'nosti studentov s raznymi sposobami vyhoda iztrudnyh zhiznennyh situacij], Scientific monograph, Grozny: ChSU, 2018, pp. 56-78.

[8] G.A. Kelley, The Psychology of Personal Constructs, V. 1,2. N.Y., 1955 / McDougall W. Outline of psychology. N.Y, 1923.

[9] R.G. Zvereva, Development of motivation for success as a condition for the formation of competitiveness of a student's personality [Razvitie motivacii dostizheniya uspekha kak uslovie formirovaniya konkurentosposobnosti lichnosti studenta], Family and Personality: Problems of Interaction [Sem'ya i lichnost': problemy vzaimodejstviya] 10, (2018) 30-37.

[10] T. Rahman, Mental Health and Purpose in Life of Drug Addicts in Bangladesh, International Forum for Logotherapy 24(2) (2001) 83-87.

[11] A. Sery, Modification of Purpose-in-Life Test, 28 Congreso Interamericano de Psicologia, Santiago, Chile, 2001, p. 127.

[12] S.S. Kashlev, Pedagogical conditions for the development of student subjectivity in the pedagogical process of the university [Pedagogicheskie usloviya razvitiya sub"ektnosti studenta V pedagogicheskom processe vuza], Retrieved from: http://charko.narod.ru/teks/sb_2002/09$\underline{\text { Kashlev.htm }}$ 